\title{
Effects of aerial hypoxia and temperature on pulmonary breathing pattern and gas exchange in the South American lungfish, Lepidosiren paradoxa
}

\author{
Glauber S.F. da Silva a,e,1, Daniela A.D.N. Ventura ${ }^{\mathrm{b}, 1}$, Lucas A. Zena ${ }^{\mathrm{a}, \mathrm{e}}$, Humberto Giusti ${ }^{\mathrm{c}}$, \\ Mogens L. Glass ${ }^{\mathrm{C}}$, Wilfried Klein ${ }^{\mathrm{d}, \mathrm{e}, *}$ \\ a College of Agricultural and Veterinarian Sciences, São Paulo State University, Brazil \\ b Master Program in Animal Diversity, Federal University of Bahia, Brazil \\ ${ }^{c}$ Faculty of Medicine of Ribeirão Preto, University of São Paulo, Brazil \\ d School of Philosophy, Sciences and Literature of Ribeirão Preto, University of São Paulo, Brazil \\ e National Institute of Science and Technology on Comparative Physiology, Rio Claro, Brazil
}

\section{A R T I C L E I N F O}

\section{Article history:}

Received 23 August 2016

Received in revised form 13 February 2017

Accepted 1 March 2017

Available online 3 March 2017

\section{Keywords:}

Dipnoi

Lung ventilation

Thermal variation

Buccal pump

\begin{abstract}
A B S T R A C T
The South American lungfish Lepidosiren paradoxa is an obligatory air-breathing fish possessing well-developed bilateral lungs, and undergoing seasonal changes in its habitat, including temperature changes. In the present study we aimed to evaluate gas exchange and pulmonary breathing pattern in L. paradoxa at different temperatures $\left(25\right.$ and $\left.30^{\circ} \mathrm{C}\right)$ and different inspired $\mathrm{O}_{2}$ levels $(21,12,10$, and $7 \%)$. Normoxic breathing pattern consisted of isolated ventilatory cycles composed of an expiration followed by $2.4 \pm 0.2$ buccal inspirations. Both expiratory and inspiratory tidal volumes reached a maximum of about $35 \mathrm{ml} \mathrm{kg}^{-1}$, indicating that L. paradoxa is able to exchange nearly all of its lung air in a single ventilatory cycle. At both temperatures, hypoxia caused a significant increase in pulmonary ventilation $\left(\dot{V}_{E}\right)$, mainly due to an increase in respiratory frequency. Durations of the ventilatory cycle and expiratory and inspiratory tidal volumes were not significantly affected by hypoxia. Expiratory time (but not inspiratory) was significantly shorter at $30{ }^{\circ} \mathrm{C}$ and at all $\mathrm{O}_{2}$ levels. While a small change in oxygen consumption $\left(\dot{V}_{2}\right)$ could be noticed, the carbon dioxide release $\left(\dot{V} \mathrm{CO}_{2}, P=0.0003\right)$ and air convection requirement $\left(\dot{V}_{E} / \dot{V} O_{2}, P=0.0001\right)$ were significantly affected by hypoxia $\left(7 \% \mathrm{O}_{2}\right)$ at both temperatures, when compared to normoxia, and pulmonary diffusion capacity increased about four-fold due to hypoxic exposure. These data highlight important features of the respiratory system of $L$. paradoxa, capable of matching $\mathrm{O}_{2}$ demand and supply under different environmental change, as well as help to understand the evolution of air breathing in lungfish.
\end{abstract}

(C) 2017 Elsevier Inc. All rights reserved.

\section{Introduction}

Among extant lungfishes, the South American Lepidosiren paradoxa and the four African species of Protopterus are obligatory air-breathers with bilateral lungs and reduced gills. Both Lepidosiren and Protopterus are crucially dependent on the lungs for gas exchange (Johansen and Lenfant, 1967; Lenfant et al., 1970). The Australian lungfish Neoceratodus forsteri, on the other hand, has a single lung combined with a well developed gill system that sustains metabolism in normoxic water (Fritsche et al., 1993). Lungfish and tetrapods share some respiratory characteristics, such as functional lungs (Bassi et al., 2005; de

\footnotetext{
* Corresponding author at: Departamento de Biologia, Faculdade de Filososfia, Ciências e Letras de Ribeirão Preto, Av. Bandeirantes 3900, Bairro Monte Alegre, 14040-901 Ribeirão Preto, SP, Brazil.

E-mail address: wklein@usp.br (W. Klein).

1 These authors contributed equally to this study.
}

Moraes et al., 2005), pulmonary surfactant (Orgeig and Daniels, 1995) and central $\mathrm{CO}_{2} / \mathrm{pH}$ chemoreceptors (Amin-Naves et al., 2007a, 2007b; Sanchez et al., 2001a).

Lepidosiren paradoxa, in Brazil locally known as pirambóia, inhabits the tropical (Amazon) and subtropical (Mato Grosso state) regions of Brazil. Their natural habitat is dominated by shallow waters covered by vegetation and the water level is constantly changing throughout the year causing seasonal droughts (Glass et al., 2009). Other seasonal changes include variations of water $\mathrm{pH}$ ranging from 6.5 to 9.0 and water temperature that may oscillate from 18 to $34{ }^{\circ} \mathrm{C}$ (Greenwood, 1986; Harder et al., 1999). Amin-Naves et al. (2004) assessed the role of aquatic and aerial gas exchange at different temperatures and demonstrated that $L$. paradoxa increases oxygen consumption at high temperature $\left(35^{\circ} \mathrm{C}\right)$ with the lungs playing a dominant role in gas exchange. In this context, the lungs also play an important role for $\mathrm{CO}_{2}$ elimination, suggesting that the temperature-dependent regulation of gas exchange in L. paradoxa resembles that of amphibians. These data 
were reported for animals exposed to aerial/aquatic normoxic environment. Da Silva et al. (2011) studied interactions between temperature and aerial hypoxia on pulmonary ventilation and blood gases in $L$. paradoxa, and as described for other tetrapods (Glass et al., 1983; Jackson, 1973; Kruhoffer et al., 1987; Munns et al., 1998), the hypoxic ventilatory response was amplified at high temperature. Currently, there are few data available on lungfish ventilation and breathing pattern during hypoxia, and data on gas exchange during hypoxia at high temperatures are lacking completely.

In a dynamic and changing environment, elevated temperature and low oxygen partial pressure are two important rationales when studying lungfish, and the physiological responses seen in present-day lungfish to such environmental conditions could highlight important physiological adaptations that may elucidate the origin of tetrapods from an aquatic lungfish-like ancestor. Firstly, because central for understanding the origin of tetrapods are the evolutionary mechanisms involved in respiratory control switching from aquatic to air breathing. Secondly, by providing a better understanding of the physiological mechanisms that have allowed lungfish to survive until today critical environmental events, such as the Middle Devonian hypoxic $\left(15 \% \mathrm{O}_{2}\right)$ atmosphere, an environmental condition that may have triggered initially the evolution of air-breathing in lungfish (Clement and Long, 2010). Pulmonary gas exchange adjustments under increased $\mathrm{O}_{2}$ demand (high temperature) and decreased $\mathrm{O}_{2}$ availability (hypoxia) are unknown for living lungfish species. However, this is an important feature regarding the respiratory system considering the environmental changes in the South American lungfish's natural habitat, the Pantanal. Moreover, the pulmonary breathing pattern of $L$. paradoxa (especially during hypoxia and high temperature) has not yet been precisely described. Therefore, the aim of the present study was to evaluate gas exchange, ventilation and breathing pattern in the South American lungfish at different temperatures and different inspired $\mathrm{O}_{2}$ levels. We did so by measuring pulmonary ventilation, oxygen consumption and carbon dioxide elimination ( $\dot{\mathrm{V}} \mathrm{O}_{2}$ and $\dot{\mathrm{V}} \mathrm{CO}_{2}$, respectively) at 25 and $30{ }^{\circ} \mathrm{C}$, and different aerial hypoxia levels.

\section{Material and methods}

\subsection{Animals}

Lepidosiren paradoxa $(N=6 ; 526 \pm 108 \mathrm{~g}$ body mass $)$ were collected in Cuiabá, Brazil, transported to the University of São Paulo, campus Ribeirão Preto and maintained in an animal care facility (authorization IBAMA no. 02027, 002172/2005-68, 46160-1). The animals were housed in $1000 \mathrm{l}$ tanks at $25^{\circ} \mathrm{C}$ and were fed every 3 days with chicken liver. All experimental protocols were carried out during the animals' active season (October to April). The experimental protocol was approved by the Ethics Committee of the Faculty of Medicine of Ribeirão Preto, University of São Paulo (Protocol no. 076/20050).

\subsection{Experimental setup}

The pneumotachographic methodology developed by Glass et al. $(1978,1983)$ was employed to measure ventilation and gas exchange. Animals were placed into a chamber and their only access to breathe air was through an inverted funnel mounted onto the top of the chamber. The funnel had a pneumotachograph attached to its outlet and inspiratory and expiratory pressure changes over the pneumotach were registered by a spirometer (FE141 ADInstruments, Sydney, Australia). Air was continuously withdrawn from the funnel at a flow rate of $50-70 \mathrm{ml} \mathrm{min}^{-1}$, and pulled by a built-in pump of the gas analyser (ML206 ADInstruments, Sydney, Australia). Data from the spirometer and gas analyser were acquired using a Powerlab system (ADInstruments, Sydney, Australia) and registered and analysed using LabChart software (ADInstruments, Sydney, Australia).
The funnel was calibrated by injection of known volumes of air, and with known $\mathrm{O}_{2}$ and $\mathrm{CO}_{2}$ composition. In all cases, regressions yielded a good fit $\left(R^{2}>0.9\right)$ and were used to transform our data to calculate tidal volume $\left(\mathrm{V}_{\mathrm{T}}\right)$, oxygen consumption $\left(\dot{V}_{2}\right)$ and carbon dioxide production $\dot{V} \mathrm{CO}_{2}$.

Hypoxic gas mixtures, provided by a Pegas 4000MF gas mixer (Columbus Instruments, Columbus, $\mathrm{OH}$, USA), were delivered directly into the funnel at a constant flow rate of $31 \mathrm{~min}^{-1}$, just as the normoxic flow of air that was being delivered during normoxia. The animal chamber was placed into an aquarium and water temperature was controlled using a thermostat (FAC Instruments, São Carlos, SP, Brazil).

\subsection{Experimental protocol}

Animals were placed into the experimental setup at least $12 \mathrm{~h}$ before measurements were initiated. Experimental temperatures used were $25^{\circ} \mathrm{C}$, followed by an increase to $30^{\circ} \mathrm{C}$, in which animals were allowed to acclimate for at least $12 \mathrm{~h}$. Ventilation and gas exchange were measured initially during normoxia for $2 \mathrm{~h}$, followed by progressively decreasing hypoxia $\left(12,10,7 \% \mathrm{O}_{2}\right)$, with the animals being exposed to each gas mixture for $3 \mathrm{~h}$.

\subsection{Data analysis}

To analyze the data, the last $120 \mathrm{~min}$ at each gas mixture were used to extract breathing frequency $\left(f_{R}\right)$, expiratory tidal volume $\left(\mathrm{V}_{\text {Texp }}\right)$, mean buccal breath volume $\left(V_{B}\right)$, the volume of the first, second and third buccal breath $\left(V_{B 1}, V_{B 2}, V_{B 3}\right.$, respectively), number of buccal breaths per ventilatory cycle $\left(\mathrm{N}_{B}\right)$, duration of expiration $\left(\mathrm{T}_{\mathrm{EXP}}\right)$, total duration of buccal inspirations $\left(\mathrm{T}_{\mathrm{INSP}}\right)$, total duration of one ventilatory cycle $\left(\mathrm{T}_{\mathrm{TOT}}=\mathrm{T}_{\mathrm{EXP}}+\mathrm{T}_{\mathrm{INSP}}\right)$, duration of non-ventilatory period $\left(\mathrm{T}_{\mathrm{NVP}}\right)$, oxygen uptake $\left(\mathrm{V}_{b} \mathrm{O}_{2}\right)$ and carbon dioxide release $\left(\mathrm{V}_{b} \mathrm{CO}_{2}\right)$ for each breath. From these data were calculated total inspiratory volume $\left(\mathrm{V}_{\text {Tinsp }}\right)$, expiratory ventilation volume $\left(\dot{V}_{E}\right)$, oxygen consumption ( $\left.\dot{V} \mathrm{O}_{2}\right)$, air convection requirement for oxygen, $\left(\dot{V}_{E} / \dot{V} O_{2}\right)$, carbon dioxide release $\left(\dot{V} C O_{2}\right)$, air convection requirement for carbon dioxide, $\left(\dot{V}_{E} \dot{V} C O_{2}\right.$ ) and the respiratory exchange ratio $\left(\dot{V} \mathrm{CO}_{2} / \dot{V} \mathrm{O}_{2}=\mathrm{RER}\right)$. Values of $\dot{V} \mathrm{O}_{2}$ and $\dot{V} \mathrm{CO}_{2}$ were corrected to STPD conditions. Data were analysed using GraphPad Prism 6.0 applying, unless otherwise stated, Repeated Measures Two-Way ANOVA followed by a Sidak's multiple comparison test. A value of $P \leq 0.05$ was considered significant. Data given represent mean \pm S.E.M.

\section{Results}

At both temperatures, normal normoxic breathing pattern of $L$. paradoxa consisted of single breaths composed of a single expiration followed by $2-4$ inspirations (Fig. 1 ) and separated by apnoeic periods of $22.9 \pm 5.1$ and $15.9 \pm 1.5 \mathrm{~min}$ at 25 and $30{ }^{\circ} \mathrm{C}$, respectively (Fig. 2d). The $\mathrm{V}_{\text {Texp }}\left(27.3 \pm 2.0 \mathrm{ml} \mathrm{kg}^{-1}\right.$ at $25{ }^{\circ} \mathrm{C}$ and $30.0 \pm$ $2.4 \mathrm{ml} \mathrm{kg}-1$ at $30^{\circ} \mathrm{C}$ ) was at both temperatures significantly lower than the $\mathrm{V}_{\text {Tinsp }}\left(37.1 \pm 3.1 \mathrm{ml} \mathrm{kg}^{-1}\right.$ at $25^{\circ} \mathrm{C}$ and $36.7 \pm 2.8 \mathrm{ml} \mathrm{kg}^{-1}$ at $30{ }^{\circ} \mathrm{C}$; Paired $t$-test, $P=0.0227$ at $25{ }^{\circ} \mathrm{C}$ and $P=0.0047$ at $30{ }^{\circ} \mathrm{C}$ ). The overall $\mathrm{V}_{\mathrm{B}}$ was $15.6 \pm 1.7 \mathrm{ml} \mathrm{kg}{ }^{-1}$ at $25{ }^{\circ} \mathrm{C}$ and $14.4 \pm$ $0.7 \mathrm{ml} \mathrm{kg}^{-1}$ at $30^{\circ} \mathrm{C}$, whereas $\mathrm{V}_{\mathrm{B} 3}$ showed a tendency to be smaller than $V_{B 1}$ and $V_{B 2}$ at both temperatures (Fig. 3). A One-Way ANOVA followed by a Holm-Sidak multiple comparison identified a significant difference between $V_{B 2}$ and $V_{B 3}$ at both temperatures during normoxia and between $V_{B 2}$ and $V_{B 3}$ at 10 and $7 \% \mathrm{O}_{2}$ at $30^{\circ} \mathrm{C}$. However, individual variation was large, since several animals showed only 2 buccal inspirations, whereas some individuals, especially the larger ones, showed up to 4 buccal inspirations. The number of buccal breaths was not significantly affected by temperature during normoxia $\left(2.4 \pm 0.2\right.$ at $25^{\circ} \mathrm{C}$ and $2.4 \pm 0.2$ at $30^{\circ} \mathrm{C}$ ) (Fig. 3). 

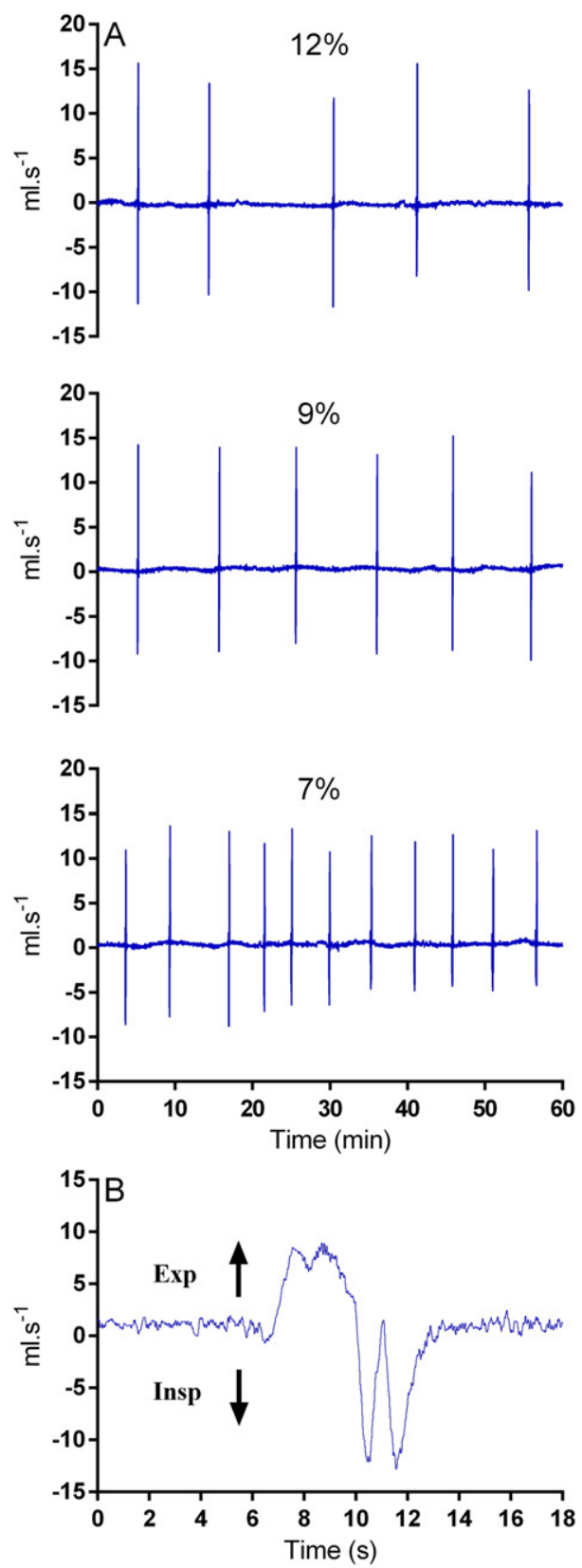

Fig. 1. Representative sample of breathing pattern of Lepidosiren paradoxa at $30{ }^{\circ} \mathrm{C}$ and different levels of $\mathrm{O}_{2}$ concentration (A) and a single ventilatory cycle consisting of an expiration followed by two buccal inspirations at $30^{\circ} \mathrm{C}(\mathrm{B})$

The RM Two-Way ANOVA identified a significant effect of hypoxia on $f_{R}, \mathrm{~N}_{\mathrm{B}}, \mathrm{V}_{\mathrm{B}}, \mathrm{T}_{\mathrm{NVP}}, \dot{V}_{E}, \dot{V} \mathrm{O}_{2}, \dot{V}_{E} / \dot{V} \mathrm{O}_{2}, \dot{V} \mathrm{CO}_{2}, \dot{V}_{E} / \dot{V} \mathrm{CO}_{2}$ and RER, a significant effect of temperature on $f_{R}, \mathrm{~T}_{\mathrm{NVP}}$, and $\dot{V}_{E}$, as well as a significant effect of the interaction of temperature and hypoxia on $f_{R}$ and $\dot{V}_{E}$.

\subsection{Effects of hypoxia}

At both temperatures $\dot{V}_{E}$ increased significantly due to a significant increase in $f_{R}$, achieved by a significant reduction in $\mathrm{T}_{\mathrm{NVP}}$ down to $8.2 \pm 0.7$ and $4.2 \pm 0.4 \mathrm{~min}$ at 25 and $30^{\circ} \mathrm{C}$, respectively (Figs. 2, 4). Similarly, the $\mathrm{N}_{\mathrm{B}}$ increased $(P=0.0024)$ during hypoxic exposures (Fig. 3). Durations of the ventilatory cycle and $V_{\text {Texp }}$ were not affected by hypoxia (Fig. 2). $V_{\text {Tinsp }}$ did not change during hypoxia, and $V_{B}$ showed a significant effect induced by hypoxia $(P=0.0131)$, but the multiple pair-wise comparison did not detect significantly different groups. $\dot{V} \mathrm{O}_{2}$ was not significantly influenced by hypoxia $(P=0.0889)$ or temperature $(P=0.5792)$ (Fig. 5). $\dot{V} C_{2}(P=0.0003)$ and $\dot{V}_{E} / \dot{V} O_{2}$ $(P=0.0001)$, on the other hand, were significantly greater at $7 \% \mathrm{O}_{2}$, at both temperatures, when compared to normoxia (Fig. 5). Compared to normoxia, $\dot{V} \mathrm{CO}_{2}$ was also significantly greater at $10 \% \mathrm{O}_{2}$ at $30^{\circ} \mathrm{C}$. Compared to normoxic values, at $30^{\circ} \mathrm{C}$ RER was significantly elevated when exposed to 12,10 , and $7 \% \mathrm{O}_{2}$, whereas at $25{ }^{\circ} \mathrm{C}$ RER was significantly greater at exposures to 10 and $7 \% \mathrm{O}_{2}$ (Fig. 5).

\subsection{Effects of temperature}

Contrary to $\mathrm{T}_{\text {INSP }}, \mathrm{T}_{\text {EXP }}$ was significantly shorter at $30{ }^{\circ} \mathrm{C}$ and at all $\mathrm{O}_{2}$ levels tested (Fig. 2a, b). This significant difference in $\mathrm{T}_{\mathrm{EXP}}$, however, did result only in a significantly lower $\mathrm{T}_{\mathrm{TOT}}$ at $10 \% \mathrm{O}_{2}$ at $30{ }^{\circ} \mathrm{C}$. $\mathrm{T}_{\mathrm{NVP}}$ was significantly lower in animals exposed to the three hypoxia levels at both temperatures (Fig. 2d). Temperature showed no significant effect on buccal ventilation (Fig. 3). At all $\mathrm{O}_{2}$ levels tested, $\dot{V}_{E}$ was significantly greater at $30^{\circ} \mathrm{C}$, whereas $f_{R}$ was significantly elevated at the higher temperature when exposing the animals to 12,10 and $7 \% \mathrm{O}_{2}$, respectively (Fig. 4c). Temperature also had a significant effect on $\dot{V}_{E} / \dot{V} C O_{2}$ at $7 \%$ $\mathrm{O}_{2}$, being greater at $30{ }^{\circ} \mathrm{C}$ than at $25^{\circ} \mathrm{C}$ (Fig. $5 \mathrm{~d}$ ).

\section{Discussion}

This is the first study to assess the combined effects of aerial hypoxia and temperature on pulmonary breathing pattern and gas exchange in the South American lungfish. Although a reduction in aquatic oxygen levels is a more realistic scenario for lungfish due to elevations in water temperature and depletion in oxygen availability due to consumption by vegetation and bacteria in swamp environments, aerial hypoxia may still be experienced by living species of lungfish. During the dry season, $L$. paradoxa can be confined to ponds with decreasing water levels within the Pantanal grassland and are forced to burrow into the mud. Natural aerial hypoxic conditions may be experienced seasonally while buried into the mud (da Silva et al., 2008; Glass, 2008; Glass et al., 2009; Sanchez, 1993) because water-logged soils show limited gas diffusion. Furthermore, from an evolutionary perspective, the combination of elevated temperature and reduced oxygen availability used in the present study, simulate the atmospheric conditions present during the Middle Devonian, the epoch when lungfish probably evolved air-breathing abilities (Clement and Long, 2010).

Independent of temperature, L. paradoxa increases pulmonary ventilation during progressive aerial hypoxia. This response is evidenced by a significant increase in air convection requirement for oxygen at both temperatures. It was shown in a previous study (da Silva et al., 2011) that the magnitude of the ventilatory response is highly temperaturedependent in L. paradoxa, which may be of adaptive importance for an animal that experiences large seasonal variations in its habitat, such as drought and environmental temperature fluctuations. Moreover, integrated cardiorespiratory responses are expected in the $\mathrm{O}_{2}$-cascade under conditions of increased $\mathrm{O}_{2}$ demand. In this regard, Costa et al. (2002, 2005) showed a temperature-induced increase in heart rate and myocardium function as temperature rose from 25 to $35^{\circ} \mathrm{C}$. Taken together, these data demonstrate the adaptive features of respiratory and cardiovascular systems of $L$. paradoxa when exposed to high temperatures. Similar to the present study, the pattern of an amplified ventilatory response to hypoxia at high temperatures was also described for toads (Kruhoffer et al., 1987) and turtles (Glass et al., 1983). Typically, at low temperatures the ventilatory responses to hypoxia were characterized by a small and discrete increase, whereas the transition from $10{ }^{\circ} \mathrm{C}$ to $30{ }^{\circ} \mathrm{C}$ increased ventilation no less than 17-fold (Glass et al., 1983).

In agreement with da Silva et al. (2011), L. paradoxa increased ventilation after a stepwise decrease in inspired $\mathrm{PO}_{2}$. The decrease in oxygen possibly stimulates internal chemoreceptors, whose location has yet to 

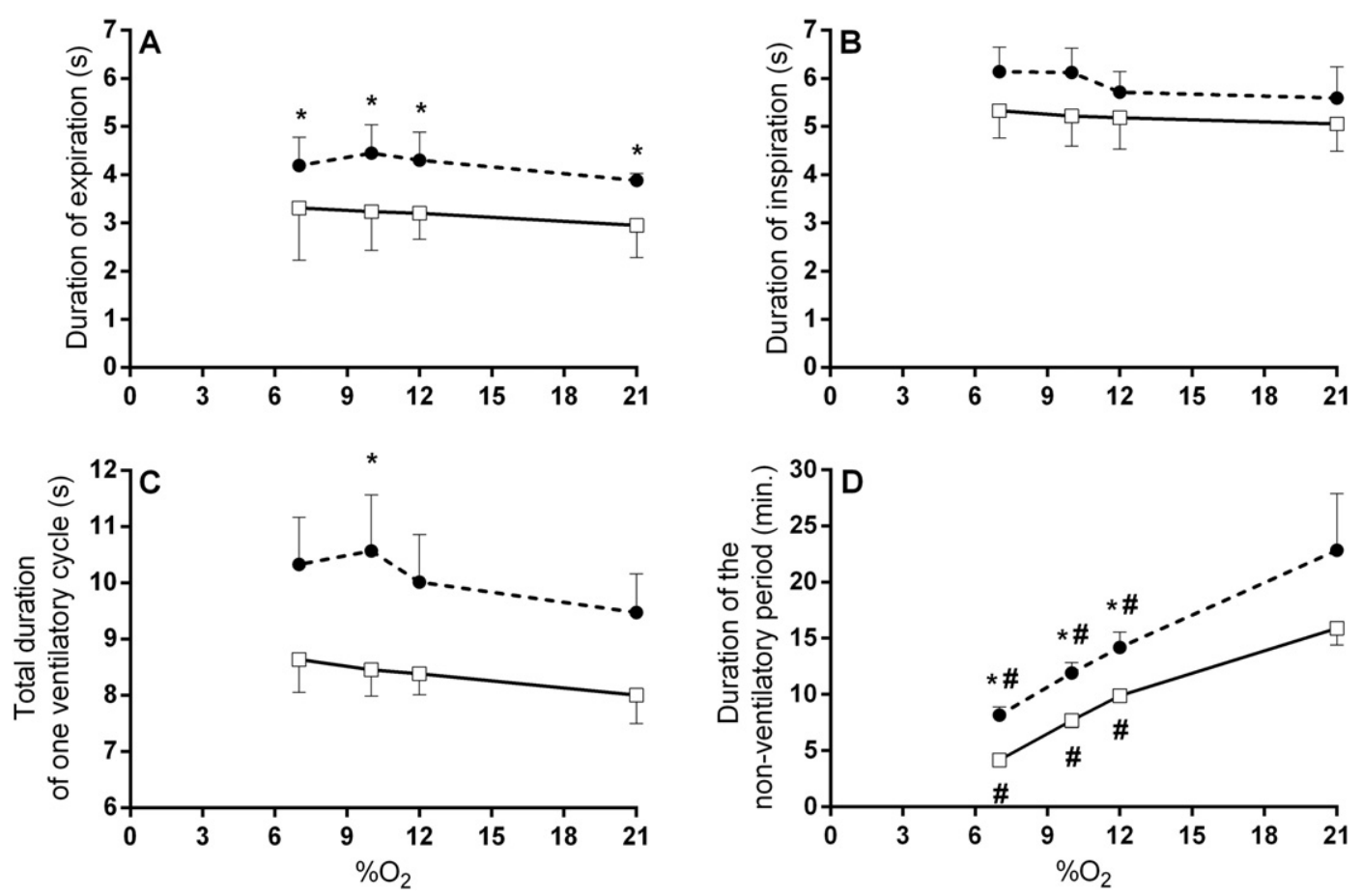

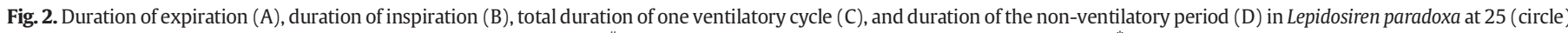

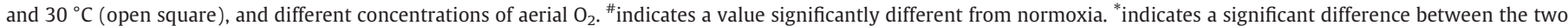
temperatures. Data are mean \pm S.E.M.

be identified, since aquatic hypoxia, which presumably acts only on external receptors, has no effect on pulmonary ventilation (Sanchez et al., 2001b). In the present study at $25^{\circ} \mathrm{C} \dot{V}_{E}$ increased significantly at $10 \%$ and $7 \% \mathrm{O}_{2}$ levels. Raising temperature to $30{ }^{\circ} \mathrm{C}$ significantly increased $\dot{V}_{E}$ relative to control values in all hypoxic levels (12\%, 10\% and $7 \%$ ). This suggests that temperature not only amplifies the magnitude, but also increases the sensitivity of the ventilatory response to hypoxia (da Silva et al., 2011, 2013; Kruhoffer et al., 1987).

In $L$. paradoxa pulmonary gas exchange is considerably diminished at lower temperature, approaching aquatic (skin and gills) gas exchange values, in which aquatic $\mathrm{CO}_{2}$ release becomes predominant over aerial values (Amin-Naves et al., 2004; Zena et al., 2017). Nevertheless, the rate of $\mathrm{O}_{2}$ transport by convective and diffusive steps in the $\mathrm{O}_{2}$ cascade must meet metabolic costs evoked during temperature rises with $L$. paradoxa expressing a four-fold increase in ventilation at $35^{\circ} \mathrm{C}$ relative to the lower temperature $\left(25^{\circ} \mathrm{C}\right.$; Amin-Naves et al., 2004; da Silva et al., 2011), as well as a four-fold increase in pulmonary diffusion capacity for the same thermal interval (Bassi et al., 2005). As proposed by Bassi et al. (2005), a reduced pulmonary inhomogeneity at higher temperature may be expressed by recruitment of more lung capillaries and/or distention of pulmonary capillaries, increasing contact surface area and thereby pulmonary diffusion capacity in this species. This increase is comparable to physiologically measured pulmonary diffusion capacities of amphibians and reptiles: (i) the American bullfrog (Lithobates catesbeianus) exhibits a two-fold increase in pulmonary diffusion capacity between 20 and $30{ }^{\circ} \mathrm{C}$, while the tegu lizard Salvator merianae and the monitor lizard Varanus exanthematicus exhibit almost three-fold increases in pulmonary diffusion capacity between 25 and $35^{\circ} \mathrm{C}$, and between 18 and $36^{\circ} \mathrm{C}$, respectively (Glass et al., 1981; Glass and Johansen, 1982). Previous morphological and physiological studies have demonstrated the distribution of diffusion capacities for the respiratory system of $L$. paradoxa (Bassi et al., 2005; de Moraes et al., 2005). While the lungs account for $\sim 99 \%$ of the total morphological diffusion capacity, resting physiological values at $25^{\circ} \mathrm{C}$ indicate that only $10 \%$ of the morphological available diffusing capacity are being used, whereas at $35^{\circ} \mathrm{C}$ up to $40 \%$ of the totally available diffusing capacity may be assessed (Bassi et al., 2005; de Moraes et al., 2005). Severe hypoxia combined with high temperature, therefore might make use of a larger percentage of the morphological available diffusing capacity in $L$. paradoxa, a pattern common to other air-breathing vertebrates.

Based on our data and those previously published by our research team, we estimated pulmonary diffusion capacity during various degrees of hypoxia at $25^{\circ} \mathrm{C}$. For this, both the $\mathrm{O}_{2}$ extraction coefficient (Dejours, 1981) and the pulmonary gas composition were calculated during hypoxia at $25{ }^{\circ} \mathrm{C}$ (combined with previously published data; da Silva et al., 2011). This information was combined with blood $\mathrm{O}_{2}$ affinity of the South American lungfish (Bassi et al., 2005). For a given $\mathrm{PO}_{2}$, SatO and $\mathrm{O}_{2}$ content were calculated using the $\mathrm{O}_{2}$ equilibrium curve (Hill coefficient and Bohr effect as described in Bassi et al., 2005). The venous $\mathrm{O}_{2}$ saturation was estimated by subtracting the percentage of $\mathrm{O}_{2}$ extraction obtained in each level of hypoxia, and venous $\mathrm{PO}_{2}$ was calculated using the Hill equation. Then, the delta $\mathrm{PO}_{2}$ and the measured $\mathrm{VO}_{2}$ were used to estimate pulmonary diffusion capacity (for details see Bassi et al., 2005). This procedure revealed pulmonary diffusion capacity values of $0.003,0.008,0.007$, and $0.011 \mathrm{ml} \mathrm{kg}^{-1} \mathrm{~min}^{-1} \mathrm{~mm} \mathrm{Hg}^{-1}$ for each level of $\mathrm{O}_{2}\left(21,12,10\right.$ and $7 \% \mathrm{O}_{2}$, respectively). Considering that $\mathrm{D}_{\mathrm{L}} \mathrm{O}_{2}$ can be calculated more accurately under hypoxic exposure, where arterial and venous $\mathrm{PO}_{2}$ are nearly linear on the steep part of the oxygen equilibrium curve, the values obtained here (0.008-0.011) are in a good agreement with those described by Bassi et al. (2005), with $\mathrm{D}_{\mathrm{L}} \mathrm{O}_{2}$ ranging from 0.009 to $0.01 \mathrm{ml} \mathrm{kg}^{-1} \mathrm{~min}^{-1} \mathrm{~mm} \mathrm{Hg}^{-1}$. The morphometric diffusing capacity for $L$. paradoxa is $0.11 \mathrm{ml} \mathrm{kg}^{-1} \mathrm{~min}^{-1} \mathrm{~mm} \mathrm{Hg}^{-1}$ (de Moraes et al., 2005), i.e. approximately an order of magnitude greater than the physiological capacity at $25^{\circ} \mathrm{C}$ and $7 \% \mathrm{O}_{2}$. At the even higher temperature of $35^{\circ} \mathrm{C}$ (Bassi et al., 2005), morphometric values would still be more than twice the value of the physiological $\mathrm{O}_{2}$ diffusing capacity. It seems that pulmonary gas exchange, by $\mathrm{O}_{2}$ diffusing capacity, apparently does not impose limits on $\mathrm{VO}_{2}$. This "excess" of diffusing capacity may be an important adaptive feature as the lung lies at the interface between the external and internal environment and therefore 

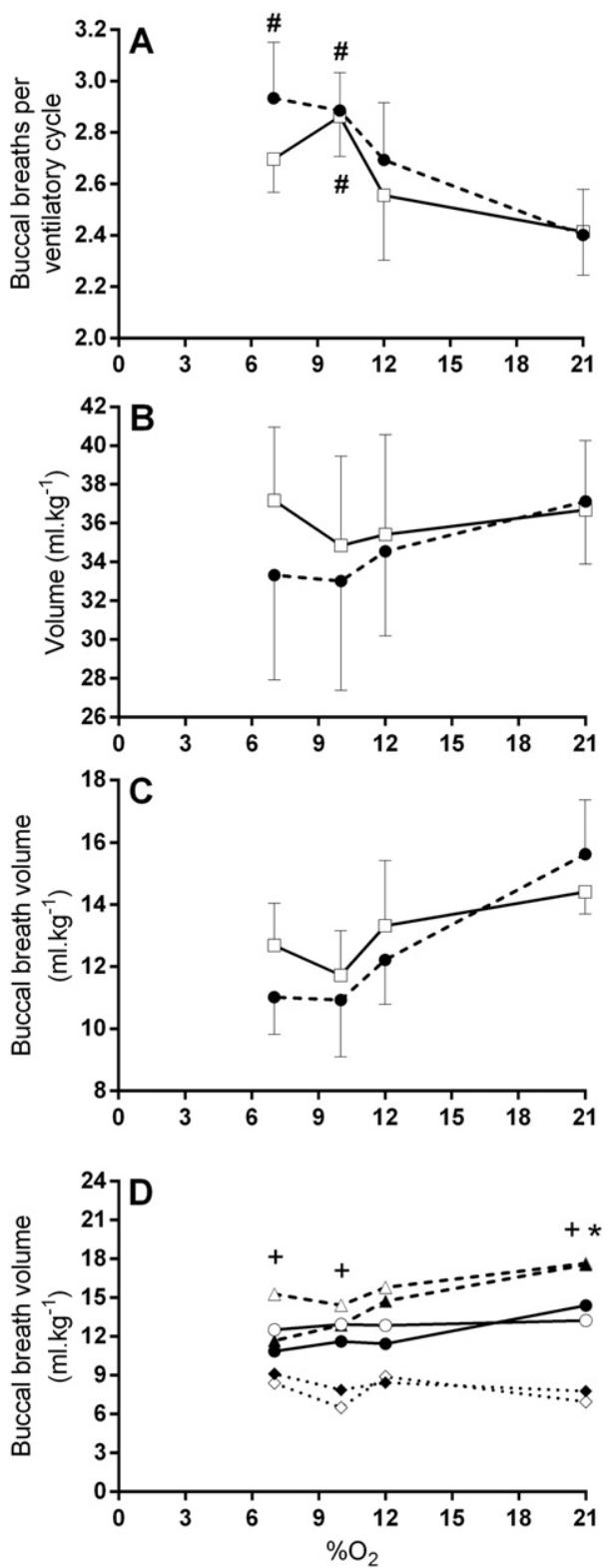

Fig. 3. Number of buccal breaths per ventilatory cycle (A), total volume of the inspiratory buccal breaths per ventilatory cycle (B), mean buccal breath volume $(C)$, and the volume of the first (circle), second (triangle) and third (diamond) buccal breath (D) in Lepidosiren paradoxa at 25 (filled symbols) and $30^{\circ} \mathrm{C}$ (open symbols), and different concentrations of aerial $\mathrm{O}_{2}$. In Fig. (D) the error bars have been omitted for reasons of clarity. " indicates a value significantly different from normoxia. *indicates a significant difference between $\mathrm{V}_{\mathrm{B} 2}$ and $\mathrm{V}_{\mathrm{B} 3}$ at $25^{\circ} \mathrm{C}$. ${ }^{+}$indicates a significant difference between $\mathrm{V}_{\mathrm{B} 2}$ and $\mathrm{V}_{\mathrm{B} 3}$ at $30^{\circ} \mathrm{C}$. Data are mean \pm S.E.M.

must adapt for variations in $\mathrm{O}_{2}$ supply from the environment (Weibel, 1999). Interestingly, Hillman et al. (2013) demonstrate that not the respiratory system but the circulatory system is the rate limiting step for oxygen to be transported from the environment to the cells, whereas lungs are generally considered to possess a larger oxygen diffusion capacity than needed to maintain aerobic metabolism, even when exercising at maximum aerobic metabolic rate. If air breathing evolved in lungfish during the Middle Devonian ( $385 \mathrm{Ma})$, as proposed by Clement and Long (2010), a time when atmospheric oxygen levels may have been as low as $12-15 \%$, the respiratory system may have needed a much larger diffusion capacity during aerobic exercise since the average temperature of earth during the Middle and Late Devonian has been estimated to be as high as $25-32{ }^{\circ} \mathrm{C}$ (Joachimski et al., 2004). Assuming that the present-day lungfish possess a similar respiratory
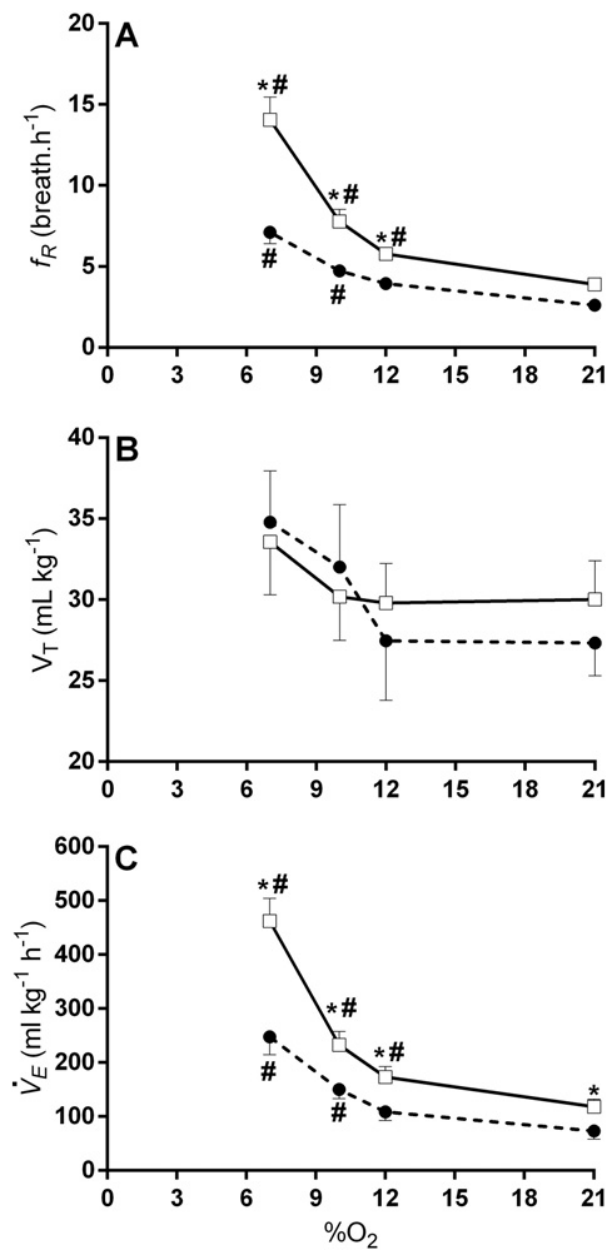

Fig. 4. Breathing frequency (A), expiratory tidal volume (B), and pulmonary ventilation volume (C) in Lepidosiren paradoxa at 25 (circle) and $30{ }^{\circ} \mathrm{C}$ (open square), and different concentrations of aerial $\mathrm{O}_{2}$. ${ }^{\#}$ indicates a value significantly different from normoxia. *indicates a significant difference between the two temperatures. Data are mean \pm S.E.M.

morphology and physiology as its ancestors, such an "excess" in diffusing capacity seen in today's air breathing vertebrates may not have been present in the early air-breathing lungfish, living under conditions of both hypoxia and elevated temperatures and it would be interesting to determine the lung diffusion capacity of lungfish under the combined effects of hypoxia, elevated temperature and maximum aerobic exercise. Since Bassi et al. (2005) found the physiological diffusion capacity for $L$. paradoxa at $35{ }^{\circ} \mathrm{C}$ under normoxia and resting conditions to be $0.044 \mathrm{ml} \mathrm{kg}^{-1} \mathrm{~min}^{-1} \mathrm{~mm} \mathrm{Hg}^{-1}$, whereas the morphological diffusion capacity has been estimated as $0.11 \mathrm{ml} \mathrm{kg}^{-1} \mathrm{~min}^{-1} \mathrm{~mm} \mathrm{Hg}^{-1}$ (de Moraes et al., 2005), we predict that under hot and hypoxic conditions physiological diffusion capacity will approximate the morphological estimate in exercising lungfish, consuming most of the "excess" in pulmonary diffusing capacity.

de Moraes et al. (2005), using stereological methods, determined lung volume in $L$. paradoxa weighing between 0.64 and $1.10 \mathrm{~kg}$ to be $25.1 \mathrm{ml} \mathrm{kg}^{-1}$. Using morphometrics, Hughes and Weibel (1976) determined in one $500 \mathrm{~g}$ Lepidosiren total lung volume to be $37.6 \mathrm{ml} \mathrm{kg}^{-1}$ and Jesse et al. (1967), using percutaneous aspiration and reinjection of air, found lung volume in three small (57-78 g) Protopterus to be $25.3 \mathrm{ml} \mathrm{kg}^{-1}$, whereas tidal volume was determined in the latter study as $19.8 \mathrm{ml} \mathrm{kg}^{-1}$. Expiratory tidal volume in the present study, using animals weighing between 420 and $680 \mathrm{~g}$ was $27.3 \mathrm{ml} \mathrm{kg}^{-1}$ at $25{ }^{\circ} \mathrm{C}$ and $30 \mathrm{ml} \mathrm{kg}^{-1}$ at $30{ }^{\circ} \mathrm{C}$. At $7 \% \mathrm{O}_{2}, \mathrm{~V}_{\text {Texp }}$ increased to 34.8 and $33.6 \mathrm{ml} \mathrm{kg}{ }^{-1}$ at 25 and $30{ }^{\circ} \mathrm{C}$, respectively, and $\mathrm{V}_{\text {Tinsp }}$ reached its greatest values at $25{ }^{\circ} \mathrm{C}$ normoxia and $30{ }^{\circ} \mathrm{C} 7 \%$ hypoxia $\left(37.1 \mathrm{ml} \mathrm{kg}^{-1}\right.$ 

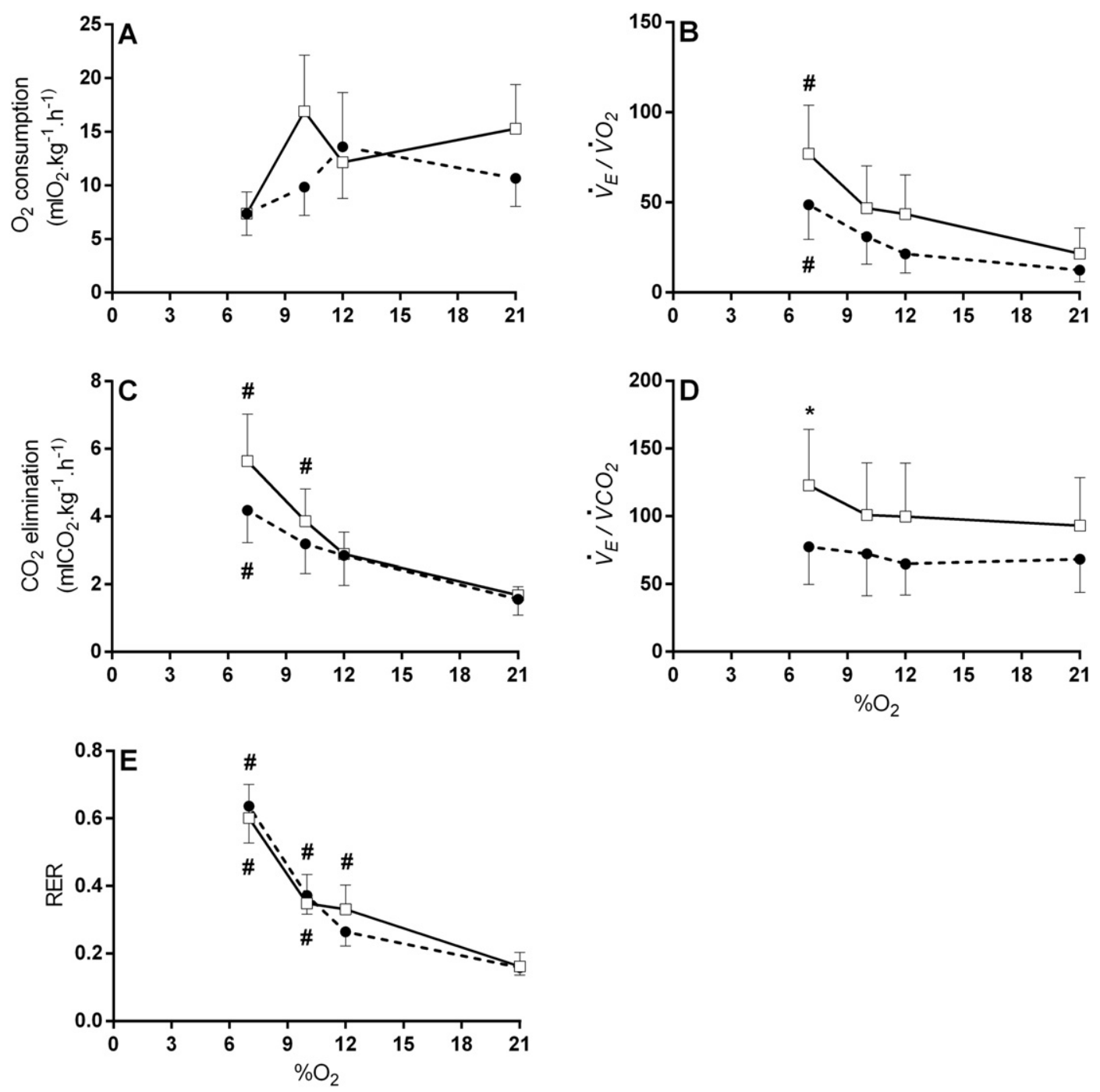

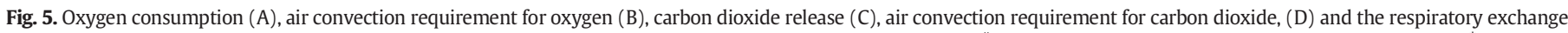

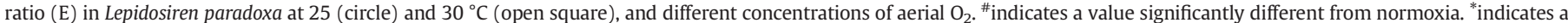
significant difference between the two temperatures. Data are mean \pm S.E.M.

and $37.2 \mathrm{ml} \mathrm{kg}^{-1}$, respectively). It seems clear, that lungfish are able to refresh in a single ventilatory cycle nearly all the air present in their lungs, thereby reducing the mixing of used and fresh air to a minimum in this two-phase buccal pump breathing mechanism and thereby being able to maintain a large $\mathrm{O}_{2}$ diffusion gradient. Maximum lung volume seems to be around $37 \mathrm{ml} \mathrm{kg}^{-1}$, as indicated by the $V_{\text {Tinsp }}$ values during hypoxia in the present study, as well maximal $\mathrm{V}_{\text {Texp }}$ values given by Harder (2001) during aerial hypoxia and hypercapnia (28.2 and $26.2 \mathrm{ml} \mathrm{kg}^{-1}$, respectively). As suggested by Harder (2001), the exchange of nearly all of the air in the lungs during each ventilatory cycle means that inspiratory and/or expiratory reserve volumes are very small in $L$. paradoxa and therefore the only possibility to increase ventilation is an increase in $\mathrm{f}_{R}$ due to a decrease in $T_{N V P}$. This pattern has been confirmed in the present study. Furthermore, the tendency of $\mathrm{V}_{\text {Texp }}$ being smaller than $\mathrm{V}_{\text {Tinsp }}$ indicates an extrapulmonary loss of $\mathrm{CO}_{2}$ to the surrounding water, and recently Zena et al. (2017) have reported that $L$. paradoxa shows a significant elimination of $\mathrm{CO}_{2}$ through the gills and integument and that this aquatic $\mathrm{CO}_{2}$ elimination increases with rising temperature. As an example, a $1 \mathrm{~kg} L$. paradoxa with a lung volume of $37 \mathrm{ml}$ would show roughly $7.8 \mathrm{ml}$ of pulmonary $\mathrm{O}_{2}$ immediately after inspiration. Assuming a metabolic rate of $0.26 \mathrm{ml} \mathrm{kg}^{-1} \mathrm{~min}^{-1}$ at $25{ }^{\circ} \mathrm{C}$ and the amount of $\mathrm{CO}_{2}$ excreted through gills and integument being $50 \%$ of total $\mathrm{CO}_{2}$ elimination (both values from Amin-Naves et al., 2004), after a 20 min breath-hold and assuming a respiratory quotient of 0.7 , the lungs would contain about $2.6 \mathrm{mlO}_{2}$ and $1.9 \mathrm{mlCO}_{2}$, decreasing total lung volume to $33.6 \mathrm{ml}$. However, only a detailed analysis of the distribution of $\mathrm{CO}_{2}$ in the different body compartments of the lungfish during normoxia, hypoxia and hypercarbia during steady state may shed light onto the lung volume decrease during the non-ventilatory period due to aquatic $\mathrm{CO}_{2}$ elimination (Malte et al., 2016).

Temperature can affect $\mathrm{CO}_{2}$ release by the pulmonary route, while the relative contribution of aquatic $\dot{V} \mathrm{CO}_{2}$ decreases with rising temperature in the South American lungfish (Amin-Naves et al., 2004; Zena et al., 2017). The thermal interval investigated in the present study (25$30{ }^{\circ} \mathrm{C}$ ) was not sufficient to cause a significant increase in pulmonary $\mathrm{CO}_{2}$ release during normoxia, besides a significant effect of temperature on ventilation. Thereby, the $\dot{V} \mathrm{CO}_{2} / \dot{V} \mathrm{O}_{2}$ ratio was also unaffected by temperature. On the other hand, hypoxia exposure elicited an increase in the $\dot{V} \mathrm{CO}_{2} / \dot{V} \mathrm{O}_{2}$ ratio influenced by the larger fraction of total $\mathrm{CO}_{2}$ output that was eliminated by the lungs.

The maximum volume of the individual buccal breaths seems to be around $15 \mathrm{ml} \mathrm{kg}^{-1}$. Thereby with two full buccal breaths and a smaller one, the lungs can be filled completely, as corroborated by the $2.4 \pm 0.2$ buccal breaths seen during normoxia. Our recordings did not indicate an expiratory air flow after the last buccal inspiration (Fig. 1B), suggesting 
that the lungfish may adjust the amount of air engulfed into the buccal cavity according to the degree of filling of the lungs (Fig. 3c). This may indicate that pulmonary stretch receptors (DeLaney et al., 1983) control buccal breath volume through negative feedback.

Harder (2001) measured ventilation and gas exchange in L. paradoxa during aerial normoxia and two levels of hypoxia (14.5 and 10\%) at $25{ }^{\circ} \mathrm{C}$ and found a significant increase in $f_{R}$ from normoxic 1.4 breaths $\mathrm{h}^{-1}$, to $2.4 \pm 0.8$ (at $14.5 \% \mathrm{O}_{2}$ ) and $2.4 \pm 0.4$ breaths $\mathrm{h}^{-1}$ (at $10.0 \% \mathrm{O}_{2}$ ). This indicates that $L$. paradoxa simply increases the number of times it surfaces to breathe at the greater temperature for all hypoxic degrees, suggesting a greater metabolic demand imposed by the elevation in temperature. This would probably affect peripheral chemoreflex sensitivity, eliciting enhanced ventilatory responses to maintain metabolism, as proposed previously for L. paradoxa (da Silva et al., 2011, 2013).

The present study also reports the pulmonary gas exchange in $L$. paradoxa. Pulmonary $\dot{V} \mathrm{O}_{2}$ has been widely described under normoxic condition for African and South American lungfish, while regarding the Australian lungfish only a measurement of oxygen concentration in expired lung air (15.8 $\pm 1.0 \%$, mean \pm S.D.) of one animal seems available (Grigg, 1965). Table 1 shows several reports of the pulmonary $\dot{V} \mathrm{O}_{2}$ from the literature. The values we found presently are in good agreement with the available literature, including previous studies from our group. We observed no change in $\dot{V} \mathrm{O}_{2}$ during hypoxia and an increase with the rise in temperature. While data are available for pulmonary $\mathrm{VO}_{2}$ at $25{ }^{\circ} \mathrm{C}$ and at greater temperatures (30 and $35{ }^{\circ} \mathrm{C}$ ), there are few reports for low temperature. Moreover, Table 1 also depicts that although $\dot{V} O_{2}$ data are roughly in the same range of values; there is some variability among species and studies (for details see the legend of Table 1). In fact, this variability was described by some studies (listed in Table 1), as it is present in our data (Fig. 5). There are some important factors that influence this variability. According to Johansen et al. (1976), the large variability of individual measurements on each fish may be elicited by differences in their activity and feeding schedule. The time of acclimation before the measurements were taken, and the time of the year also may contribute to augment variability. Recently, Lee and Milsom (2016) showed that the time interval used to analyze gas exchange data, significantly influences the results, the longer the trace analyzed, the better the obtained data. Moreover, the developmental stage can play an important role (Babiker, 1979; Johansen et al., 1976; McMahon, 1970; Perry et al., 2005). In small animals the aquatic gas exchange is dominant over the aerial gas exchange (Babiker, 1979; Johansen et al., 1976). In this regard, no information is available for $L$. paradoxa. The African lungfish, P. amphibius, gradually develops the ability of extracting the majority (total or nearly all) of its oxygen requirement from atmospheric air, with a dramatic reduction in aquatic gas exchange (Johansen et al., 1976). In this context, it is interesting to note that adult $L$. paradoxa exposed to low temperature $\left(15^{\circ} \mathrm{C}\right)$ presented a decreased pulmonary gas exchange, and the relative contribution of aquatic gas exchange was increased (Amin-Naves et al., 2004).

Severe hypoxia in the gas phase $\left(7 \% \mathrm{O}_{2}\right)$ elicited ventilatory responses by increasing $f_{R}$ and $\mathrm{N}_{\mathrm{B}}$, reducing $\mathrm{T}_{\mathrm{NVP}}$, but maintaining $\mathrm{T}_{\mathrm{INSP}}$ and $\mathrm{T}_{\mathrm{EXP}}$, and thereby $\mathrm{T}_{\mathrm{TOT}}$, constant in $L$. paradoxa. A similar pattern is also exhibited by aquatic testudines (Cordeiro et al., 2016), and, as proposed by Vitalis and Milsom (1986), may represent an adaptive mechanism to minimize the mechanical cost of breathing. The thermal increase from 25 to $30{ }^{\circ} \mathrm{C}$ applied in the present study decreased $\mathrm{T}_{\text {EXP }}$ significantly, but was not sufficient to affect significantly $\mathrm{T}_{\text {INSP }}$ and

Table 1

Values reported in the literature for pulmonary $\dot{V O}_{2}$ at different temperatures under normoxic condition in the air phase for different species of lungfish.

\begin{tabular}{|c|c|c|c|c|c|}
\hline Reference & Species & $N$ & Body mass (g) & Temperature $\left({ }^{\circ} \mathrm{C}\right)$ & $\begin{array}{l}\dot{\mathbf{V} \boldsymbol{O}_{2}} \\
\left(\mathrm{ml} \mathrm{STPD} \mathrm{kg}^{-1} \mathrm{~h}^{-1}\right)\end{array}$ \\
\hline Amin-Naves et al., 2004 & L. paradoxa & 5 & 480 & 15 & 3.6 \\
\hline Johansen and Lenfant, 1967 & L. paradoxa & 2 & $104-212$ & 20 & 53.4 \\
\hline Present Study & L. paradoxa & 6 & 526 & 25 & 10.7 \\
\hline Amin-Naves et al., 2004 & L. paradoxa & 6 & 480 & 25 & 15.6 \\
\hline Sanchez et al., 2005 & L. paradoxa & 6 & $400-650$ & 25 & 19.2 \\
\hline Bassi et al., 2005 & L. paradoxa & 8 & 486 & 25 & 15.6 \\
\hline Abe and Steffensen, 1996 & L. paradoxa & 10 & 480 & 25 & 20.1 \\
\hline Harder, 2001 & L. paradoxa & 5 & $292-1230$ & 25 & 23.4 \\
\hline Juca-Chagas, 2004 & L. paradoxa & 11 & 29-194 & 25 & 15.6 \\
\hline Sawaya, 1946 & L. paradoxa & 1 & 450 & $25-30$ & 35 \\
\hline Present Study & L. paradoxa & 6 & 526 & 30 & 15.3 \\
\hline Amin-Naves et al., 2004 & L. paradoxa & 7 & 480 & 35 & 43.8 \\
\hline Bassi et al., 2005 & L. paradoxa & 5 & 560 & 35 & 54.6 \\
\hline Johansen et al., 1976 & P. amphibius & - & 4 & $30^{\mathrm{a}}$ & $\sim 21$ \\
\hline Johansen et al., 1976 & P. amphibius & - & 42 & $30^{\mathrm{a}}$ & $\sim 43$ \\
\hline Johansen et al., 1976 & P. amphibius & - & 168 & $30^{a}$ & $\sim 50$ \\
\hline Johansen et al., 1976 & P. amphibius & - & 257 & $30^{\mathrm{a}}$ & $\sim 25$ \\
\hline Johansen et al., 1976 & P. amphibius & - & 337 & $30^{\mathrm{a}}$ & $\sim 30$ \\
\hline Johansen et al., 1976 & P. amphibius & - & 469 & $30^{\mathrm{a}}$ & $\sim 34$ \\
\hline Lenfant and Johansen, 1968 & P. aethiopicus & 4 & - & 20 & 12 \\
\hline DeLaney et al., 1974 & P. aethiopicus & 5 & 2000 to 6000 & 25 & 12 to 31 \\
\hline McMahon, 1970 & P. aethiopicus & 4 & $150-600$ & 24 & 62.5 \\
\hline Perry et al., 2005 & P. dolloi & 11 & 159 & 25 & 17.9 \\
\hline Perry et al., 2008 & P. dolloi & 11 & 146 & 25 & 21.3 \\
\hline
\end{tabular}

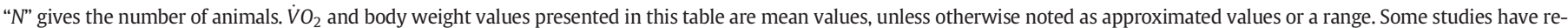

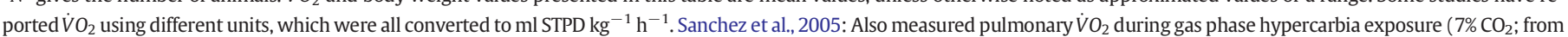

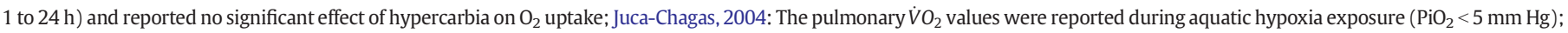

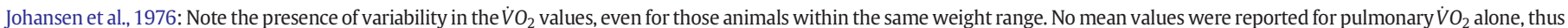

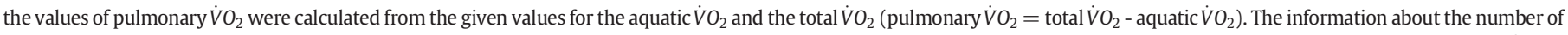

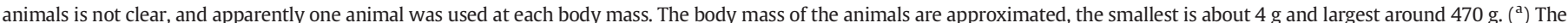

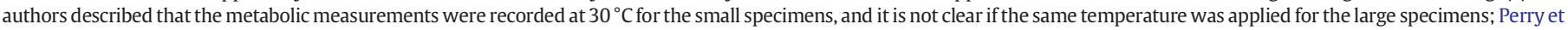

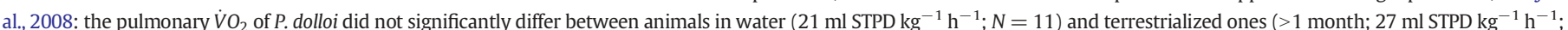

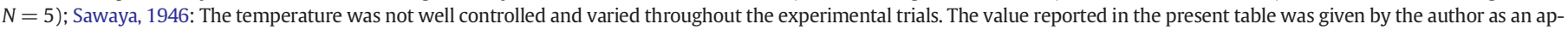

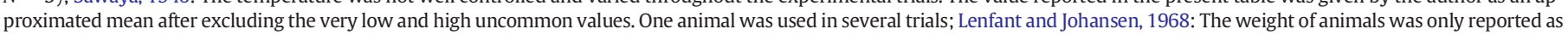
being large animals. 
$\mathrm{T}_{\mathrm{TOT}}$, besides both variables showing a tendency to be greater at $30^{\circ} \mathrm{C}$. In contrast, at the higher temperature $\mathrm{T}_{\mathrm{NVP}}$ was lower during normoxia and significantly smaller during hypoxia, when compared to $25{ }^{\circ} \mathrm{C}$. The ventilatory pattern observed in normoxia with an expiration followed by 2-4 buccal inspirations is similar to breathing pattern in Protopterus aethiopicus (DeLaney and Fishman, 1977), and affected by hypoxia, increasing $\mathrm{N}_{\mathrm{B}}$ slightly to $2.9\left(25^{\circ} \mathrm{C}\right)$ and $2.7\left(30^{\circ} \mathrm{C}\right)$. L. paradoxa never showed two or more consecutive ventilatory cycles, i.e. an episode of breaths as seen frequently in other ectothermic air breathers (e.g. Cordeiro et al., 2016; Glass and Wood, 1983; Munns et al., 1998; Shelton et al., 1986).

\subsection{Conclusion}

In conclusion, the present study described the pulmonary breathing pattern and gas exchange in the South American lungfish L. paradoxa during combined effects of temperature and aerial hypoxia. Our data demonstrate that temperature amplifies the magnitude of hypoxic ventilatory responses by mainly decreasing the non-ventilatory period, and consequently increasing respiratory frequency, and emphasize the dominant role of the lungs in gas exchange under the present experimental conditions. These animals present a pulmonary breathing pattern characterized by an expiration followed by a series of buccal inspirations, which suffice to exchange nearly all air of the lungs in one ventilatory cycle. Furthermore, the present study may shed some light onto the evolution of air breathing in sarcopterygians and their transition from aquatic to terrestrial environments during the Middle Devonian, which has been suggested to involve increases in metabolic costs due to moving between different environments, in addition to the evolution of air-breathing having possibly occurred in a hot and hypoxic environment of the Devonian period.

\section{Transparency Document}

The Transparency document associated with this article can be found, in the online version.

\section{Acknowledgements}

Funding: This study was financially supported by the Fundação de Ampara à Pesquisa do Estado de São Paulo (FAPESP no. 2008/577124) and Conselho Nacional de Desenvolvimento Científico e Tecnológico (CNPq no. 573921/2008-3), through the National Institute of Science and Technology on Comparative Physiology (INCT em Fisiologia Comparada). G.S.F. da Silva is supported by a Young Investigator Award (FAPESP no 2013/17606-9 and 2014/12190-1). L.A.Z. was the recipient of FAPESP PhD fellowship (no. 12/17379-0).

\section{References}

Abe, A.S., Steffensen, J.F., 1996. Respiração pulmonar e cutânea na pirambóia, Lepidosiren paradoxa, durante a atividade e a estivação (Osteichthyes, Dipnoi). Rev. Bras. Biol. 56, 485-489.

Amin-Naves, J., Giusti, H., Glass, M.L., 2004. Effects of acute temperature changes on aerial and aquatic gas exchange, pulmonary ventilation and blood gas status in the South American lungfish, Lepidosiren paradoxa. Comp. Biochem. Physiol. A Mol. Integr. Physiol. 138, 133-139.

Amin-Naves, J., Giusti, H., Hoffmann, A., Glass, M.L., 2007a. Central ventilatory control in the South American lungfish, Lepidosiren paradoxa: contributions of $\mathrm{pH}$ and $\mathrm{CO}_{2}$. J. Comp. Physiol. B. 177, 529-534.

Amin-Naves, J., Giusti, H., Hoffmann, A., Glass, M.L., 2007b. Components to the acid-base related ventilatory drives in the South American lungfish Lepidosiren paradoxa. Respir. Physiol. Neurobiol. 155, 35-40.

Babiker, M.M., 1979. Respiratory behaviour, oxygen consumption and relative dependence on aerial respiration in the African lungfish (Protopterus annectens, Owen) and an air-breathing teleost (Clarias lazera, C.). Hydrobiologia 65, 177-187.

Bassi, M., Klein, W., Fernandes, M.N., Perry, S.F., Glass, M.L., 2005. Pulmonary oxygen diffusing capacity of the South American lungfish Lepidosiren paradoxa: physiological values by the Bohr method. Physiol. Biochem. Zool. 78, 560-569.
Clement, A.M., Long, J.A., 2010. Air-breathing adaptation in a marine Devonian lungfish. Biol. Lett. 6, 509-512

Cordeiro, T.E., Abe, A.S., Klein, W., 2016. Ventilation and gas exchange in two turtles: Podocnemis unifilis and Phrynops geoffroanus (Testudines: Pleurodira). Respir. Physiol. Neurobiol. 224, 125-131.

Costa, M.J., Olle, C.D., Ratto, J.A., Anelli Jr., L.C., Kalinin, A.L., Rantin, F.T., 2002. Effect of acute temperature transition on chronotropic and inotropic responses of the South American lungfish Lepidosiren paradoxa. J. Therm. Biol. 27, 39-45.

Costa, M.J., Olle, C.D., Rantin, F.T., Kalinin, A.L., 2005. Influence of temperature on calcium sensitivity in the ventricular myocardium of the South American lungfish: effects of extracellular calcium and adrenaline. J. Therm. Biol. 30, 259-266.

Dejours, P., 1981. Principles of Comparative Respiratory Physiology. second ed. Elsevier, North Holland.

DeLaney, R.G., Fishman, A.P., 1977. Analysis of lung ventilation in the aestivating lungfish Protopterus aethiopicus. Am. J. Phys. 233, R181-R187.

Delaney, R.G., Lahiri, S., Fishman, A.P., 1974. Aestivation of the African lungfish Protopterus aethiopicus: cardiovascular and respiratory functions. J. Exp. Biol. 61, 111-128.

DeLaney, R.G., Laurent, P., Galante, R., Pack, A.I., Fishman, A.P., 1983. Pulmonary mechanoreceptors in the dipnoi lungfish Protopterus and Lepidosiren. Am. J. Phys. 244 R418-R428.

Fritsche, R., Axelsson, M., Franklin, C.E., Grigg, G.G., Holmgren, S., Nilsson, S., 1993. Respiratory and cardiovascular responses to hypoxia in the Australian lungfish. Respir Physiol. 94, 173-187.

Glass, M.L., 2008. The enigma of aestivation in the African lungfish Protopterus dolloi-commentary on the paper by Perry et al. Respir. Physiol. Neurobiol. 160 $18-20$.

Glass, M.L., Johansen, K., 1982. Pulmonary oxygen diffusing capacity of the lizard Tupinambis teguixin. J. Exp. Zool. 219, 385-388.

Glass, M.L., Wood, S.C., 1983. Gas exchange and control of breathing in reptiles. Physiol. Rev. 63, 232-260.

Glass, M.L., Wood, S.C., Johansen, K., 1978. The application of pneumotachography on small unrestrained animals. Comp. Biochem. Physiol. A Physiol. 59, 425-427.

Glass, M.L., Johansen, K., Abe, A.S., 1981. Pulmonary diffusing capacity in reptiles (relations to temperature and $\mathrm{O}_{2}$-uptake). J. Comp. Physiol. B. 142, 509-514.

Glass, M.L., Boutilier, R.G., Heisler, N., 1983. Ventilatory control of arterial $\mathrm{PO}_{2}$ in the turtle, Chrysemys picta bellii: effects of temperature and hypoxia. J. Comp. Physiol. B. 151, 145-153.

Glass, M.L., Amin-Naves, J., da Silva, G.S., 2009. Aestivation in amphibians, reptiles and lungfish. In: Glass, M.L., Wood, S.C. (Eds.), Cardio-Respiratory Control in Vertebrates: Comparative and Evolutionary Aspects. Springer-Verlag, Berlin Heidelberg, pp. 179-189.

Greenwood, P.H., 1986. The natural history of African lungfishes. J. Morphol. 190, 163-179 (Suppl.)

Grigg, G.C., 1965. Studies on the Queensland lungfish, Neoceratodus forsteri (Krefft). 1. Anatomy, histology, and functioning of the lungs. Aust. J. Zool. 13, 243-253.

Harder, V., 2001. Untersuchungen zur bimodalen Atmung des südamerikanischen Lungenfisches Lepidosiren paradoxa (Fitz.) - in situ und in vivo. (Dissertation) Universität Düsseldorf. Shaker-Verlag, Aachen.

Harder, V., Souza, R.H.S., Severi, W., Rantin, F.T., Bridges, C.R., 1999. The South American lungfish: adaptations to an extreme habitat. In: Val, A.L., Almeida-Val, V.M.F. (Eds.), Biology of Tropical Fishes. INPA, Manaus, pp. 99-110.

Hillman, S.S., Hancock, T.V., Hedrick, M.S., 2013. A comparative meta-analysis of maximal aerobic metabolism of vertebrates: implications for respiratory and cardiovascular limits to gas exchange. J. Comp. Physiol. B. 183, 167-179.

Hughes, G.M., Weibel, E.R., 1976. Morphometry of fish lungs. In: Hughes, G.M. (Ed.) Respiration of Amphibious Vertebrates. Academic Press, London, pp. 213-232.

Jackson, D.C., 1973. Ventilatory response to hypoxia in turtles at various temperatures. Respir. Physiol. 18, 178-187.

Jesse, M.J., Shub, C., Fishman, A.P., 1967. Lung and gill ventilation of the African lung fish. Respir. Physiol. 3, 267-287.

Joachimski, M.M., van Geldern, R., Breisig, S., Buggisch, W., Day, J., 2004. Oxygen isotope evolution of biogenic calcite and apatite during the Middle and Late Devonian. Int J. Earth Sci. 93, 542-553.

Johansen, K., Lenfant, C., 1967. Respiratory function in the South American lungfish, Lepidosiren paradoxa (Fitz). J. Exp. Biol. 46, 205-218.

Johansen, K., Lomholt, J.P., Maloiy, G.M., 1976. Importance of air and water breathing in relation to size of the African lungfish Protopterus amphibius Peters. J. Exp. Biol. 65 , 395-399.

Juca-Chagas, R., 2004. Air breathing of the neotropical fishes Lepidosiren paradoxa, Hoplerythrinus unitaeniatus and Hoplosternum littorale during aquatic hypoxia. Comp. Biochem. Physiol. A Mol. Integr. Physiol. 139, 49-53.

Kruhoffer, M., Glass, M.L., Abe, A.S., Johansen, K., 1987. Control of breathing in an amphibian Bufo paracnemis: effects of temperature and hypoxia. Respir. Physiol. 69, 267-275

Lee, S.Y., Milsom, W.K., 2016. The metabolic cost of breathing in red-eared sliders: an attempt to resolve an old controversy. Respir. Physiol. Neurobiol. 224, 114-124.

Lenfant, C., Johansen, K., 1968. Respiration in the African lungfish Protopterus aethiopicus I. Respiratory properties of blood and normal patterns of breathing and gas exchange. J. Exp. Biol. 49, 437-452.

Lenfant, C., Johansen, K., Hanson, D., 1970. Bimodal gas exchange and ventilation-perfusion relationship in lower vertebrates. Fed. Proc. 29, 1124-1129.

Malte, C.L., Malte, H., Wang, T., 2016. The long road to steady state in gas exchange: metabolic and ventilatory responses to hypercapnia and hypoxia in Cuvier's dwarf caiman. J. Exp. Biol. 219, 3810-3821.

McMahon, B.R., 1970. The relative efficiency of gaseous exchange across the lungs and gills of an African lungfish Protopterus aethiopicus. J. Exp. Biol. 52, 1-15 
de Moraes, M.F., Holler, S., da Costa, O.T., Glass, M.L., Fernandes, M.N., Perry, S.F., 2005 Morphometric comparison of the respiratory organs in the South American lungfish Lepidosiren paradoxa (Dipnoi). Physiol. Biochem. Zool. 78, 546-559.

Munns, S.L., Frappell, P.B., Evans, B.K., 1998. The effects of environmental temperature, hypoxia, and hypercapnia on the breathing pattern of saltwater crocodiles (Crocodylus porosus). Physiol. Zool. 71, 267-273.

Orgeig, S., Daniels, C.B., 1995. The evolutionary significance of pulmonary surfactant in lungfish (Dipnoi). Am. J. Respir. Cell Mol. Biol. 13, 161-166.

Perry, S.F., Gilmour, K.M., Vulesevic, B., McNeill, B., Chew, S.F., Ip, Y.K., 2005. Circulating catecholamines and cardiorespiratory responses in hypoxic lungfish (Protopterus dolloi): a comparison of aquatic and aerial hypoxia. Physiol. Biochem. Zool. 78, $325-334$.

Perry, S.F., Euverman, R., Wang, T., Loong, A.M., Chew, S.F., Ip, Y.K., Gilmour, K.M., 2008. Control of breathing in African lungfish (Protopterus dolloi): a comparison of aquatic and cocooned (terrestrialized) animals. Respir. Physiol. Neurobiol. 160, 8-17.

Sanchez, J.P., 1993. Breathing in the aestivating African lungfish, Protopterus amphibicus. In: Singh, B.R. (Ed.), Advances in Fish Research. Narendra, New Delhi, pp. 17-34.

Sanchez, A.P., Hoffmann, A., Rantin, F.T., Glass, M.L., 2001a. Relationship between cerebrospinal fluid $\mathrm{pH}$ and pulmonary ventilation of the South American lungfish, Lepidosiren paradoxa (Fitz.). J. Exp. Zool. 290, 421-425.

Sanchez, A., Soncini, R., Wang, T., Koldkjaer, P., Taylor, E.W., Glass, M.L., 2001b. The differential cardio-respiratory responses to ambient hypoxia and systemic hypoxaemia in the South American lungfish, Lepidosiren paradoxa. Comp. Biochem. Physiol. A Mol. Integr. Physiol. 130, 677-687.
Sanchez, A.P., Giusti, H., Bassi, M., Glass, M.L., 2005. Acid-base regulation in the South American Lungfish Lepidosiren paradoxa: effects of prolonged hypercarbia on blood gases and pulmonary ventilation. Physiol. Biochem. Zool. 78, 908-915.

Sawaya, P., 1946. Sobre a biologia de alguns peixes de respiração aérea. Bol. Zool. Biol. Mar. 11, 255-285

Shelton, G., Jones, D.R., Milsom, W.K., 1986. Control of breathing in ectothermic vertebrates. In: Cherniack, N.S., Widdicombe, J.G. (Eds.), Handbook of Physiology, Sect 3. The Respiratory System, Vol. 2. Control of Breathing. American Physiological Society, Bethesda, pp. 857-909.

da Silva, G.S., Giusti, H., Sanchez, A.P., do Carmo, J.M., Glass, M.L., 2008. Aestivation in the South American lungfish, Lepidosiren paradoxa: effects on cardiovascular function, blood gases, osmolality and leptin levels. Respir. Physiol. Neurobiol. 164, 380-385.

da Silva, G.S., Giusti, H., Branco, L.G., Glass, M.L., 2011. Combined ventilatory responses to aerial hypoxia and temperature in the South American lungfish Lepidosiren paradoxa. J. Therm. Biol. 36, 521-526.

da Silva, G.S., Glass, M.L., Branco, L.G., 2013. Temperature and respiratory function in ectothermic vertebrates. J. Therm. Biol. 38, 55-63.

Vitalis, T.Z., Milsom, W.K., 1986. Mechanical analysis of spontaneous breathing in the semi-aquatic turtle, Pseudemys scripta. J. Exp. Biol. 125, 157-171.

Weibel, E.R., 1999. Understanding the limitation of $\mathrm{O}_{2}$ supply through comparative physiology. Respir. Physiol. 118, 85-93.

Zena, L.A. Bícego, K.C. da Silva, G.S.F., Giusti, H. Glass, M.L, Sanchez, A.P. 2017. Acute effects of temperature and hypercarbia on cutaneous and branchial gas exchange in the South American lungfish, Lepidosiren paradoxa. J. Therm. Biol. 63, 112-118. 